DOI: $10.6060 / \mathrm{mhc} 131163 \mathrm{~m}$

\title{
Nanostructure of Zinc(II) Tetraphenylporphyrinate Langmuir M-Monolayers Formed with Diluted Solution
}

\author{
M. V. Petrova, ${ }^{a}$ L. A. Maiorova, ${ }^{a}$ O. A. Gromova, ${ }^{b}$ T. A. Bulkina, ${ }^{a}$ T. A. Ageeva, ${ }^{a}$ \\ and O. I. Koifman ${ }^{\mathrm{a}, \mathrm{c}}$ \\ ${ }^{a}$ Research Institute of Macroheterocyclic Compounds, Ivanovo State University of Chemistry and Technology, 153000 \\ Ivanovo, Russia \\ ${ }^{\mathrm{b}} \mathrm{RSC}$ "Neurobiology" of trace institute of UNESCO, Moscow, Russia \\ 'Institute of Solution Chemistry of RAS, 153045 Ivanovo, Russia \\ ${ }^{\circledR}$ Corresponding authorE-mail: karljukmaria@rambler.ru
}

\begin{abstract}
Using quantitative analysis of isotherms the main characteristics of the structure of zinc tetraphenylporphyrinate (ZnTPP) floating M-monolayers formed with diluted solution have been determined. These include the size of $M$-nanoaggregates and the number of molecules in them, the distance between aggregates, the content of bound water and water between aggregates, the compressibility, and the pressure and current surface concentration ranges corresponding to stable states. The dependencies of main characteristics from the initial surface coverage found allow one to estimate the highest aggregation number.
\end{abstract}

Keywords: Nanostructure, 2D-nanoaggregates, Langmuir $M$-monolayers, zinc tetraphenylporphyrinate.

\section{Наноструктура ленгмюровских $M$-монослоев тетрафенилпорфирината цинка(II), сформированных с использованием раствора низкой концентрации}

\author{
М. В. Петрова, ${ }^{a}$ ᄉ. А. Майорова, ${ }^{\text {a }}$ О. А. Громова, ${ }^{\text {b }}$ T. А. Булкина, ${ }^{\text {a }}$ T. А. Агеева, ${ }^{a}$ \\ О. И. Койфрман ${ }^{\text {а,с }}$
}

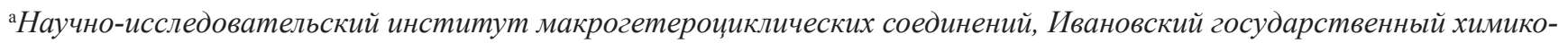
технологический университет, 153000 Иваново, Россия

${ }^{\mathrm{b}}$ Научно-исследовательский иентр «Нейробиология», ЮНЕСКО, Москва, Россия

'Инситут химии растворов РАН, 153045 Иваново, Россия

${ }^{\circledR}$ E-mail: karljukmaria@rambler.ru

\begin{abstract}
С использованием метода количественного анализа изотерм определены основные характеристики плаваюших M-монослоев тетрафенилпорфирината цинка (ZnTPP), сформированных из раствора малой концентрации ZnTPP. В частности, были определены: размер двумерных наноагрегатов, число молекул в них, расстояние между агрегатами, содержание связанной воды и воды между агрегатами, сжимаемость монослоя, область сущеествования стабильного монослоя по давлению и текущеей поверхностной конщентрации. Установленная зависимость основных характеристик слоя от начальной степени покрытия поверхности позволила определить максимально возможное количество молекул в двумерных наноагрегатах ZnTPP.
\end{abstract}

Ключевые слова: Наноструктура, 2D-наноагрегаты, $M$-монослои Ленгмюра, тетрафенилпорфиринат цинка. 


\section{Introduction}

Porphyrins which are aromatic macroheterocyclic compounds forming a specific class of organic ligands represent the components of perspective materials and important constituents of live matter. Feasibility of such compounds greatly depends on advances in methods of fabrication of functional materials. ${ }^{[1-3]}$ Porphyrins are highly stable and tend to coalesce into supramolecular structures, so called stacks or one-dimensional aggregates. The aggregation takes place both in solutions (similar to formation of bandlike structures in classic amphyphilic substances ${ }^{[4,5]}$ ) and in thin films (similar to formation of layered liquid-crystalline structures ${ }^{[6-8]}$ ). Said aggregation phenomena may be used as a natural tool for fabrication of functional nanosized and nanostructured materials. ${ }^{[9-11]}$ The main difficulty in fabrication of such materials is how to control positioning of the molecules, ${ }^{[12-14]}$ that is why the development of methods for controlled self-assembly of molecules is so important. [15,16] A formation of molecular layers at the liquid-air interface used in the LB technique provides possibilities for self-organization of the molecules not only in 3D-aggregates, but in 2D-nanostructures of different size as well. The latter consist of major nanoaggregates with diameter is in the range of 5-20 nm (M-aggregates).$^{[17-23]}$ By using the LB technique, one can examine interactions between main component and partner compounds (including natural ones), create artificial membranes etc. ${ }^{[24-26]}$ Floating layers are described by Volmer equation $^{[27]}$ generalized for the case where nanoaggregates are structural elements of the layer. ${ }^{[28,29]}$ Approaches for modeling of such layers are being elaborated; ${ }^{[30]}$ first physical model of the layer is built and mathematically described. [30b,c] The model is tested against some copper and cobalt azaporphyrins with several substitutes. ${ }^{[31-34]}$

The present work is aimed for investigation of formation of nanoaggregates in Langmuir layers formed with diluted solution of zinc tetraphenylporphyrinate (ZnTPP); determination of parameters of the ZnTPP floating layer at varying initial surface coverage $\left(c_{\text {face }}\right)$; formation of stable M-monolayers with dissimilar structure of two-dimensional nanoaggregates.

\section{Experimental}

The compound under study was synthesized according to techniques described elsewhere. ${ }^{[35]}$ To produce a floating layer, the solution of the ZnTPP in chloroform $\left(C=2.25 \cdot 10^{-5} \mathrm{~mol} \cdot \mathrm{L}^{-1}\right)$ was deposited onto the surface of twice distilled water in the Langmuir trough (NT-MDT, Russia) using precision microsyringes $(10,25$, and $100 \mu \mathrm{L}$, Hamilton, Sweden) at $(20 \pm 1){ }^{\circ} \mathrm{C}$. Then $15 \mathrm{~min}$ after the deposition a layer was compressed at $4.2 \mathrm{~cm}^{2} / \mathrm{min}$. The initial degree of coverage of water surface by the porphyrin $\left(c_{\text {face }}\right)$ was varied from 8 to $12 \%$; the accuracy of determination of the area per molecule $(A)$ is $2 \%$. The surface pressure was measured with a Wilhelmy balance with the accuracy of $0.02 \mathrm{mN} \cdot \mathrm{m}^{-1}$. The values of area per molecule in a nanoaggregate $\left(A_{\text {mol }}\right)$ and aggregation number $(n)$ were determined by linear least squares approximation of the part of the $\pi A-\pi$ plot (the error of the $\pi A$ value is less than $3 \%$ ). The error of determination of layer parameters does not exceed $3 \%$ for $A_{\text {mol }}$ and $\Delta \pi ; 5 \%$ for $c_{\text {face }}, c_{i \text {-face }}, c_{f-\text { face, }}$ and $r ; 7 \%$ for $D$ and $w_{\text {inter-M-i } i}$; $10 \%$ for $B, c_{i-a g g}, n, w_{i n-M}$, and $d_{\mathrm{i}}$.

\section{Results and Discussion}

The structure of layers was analyzed within the framework of the model and the method of qualitative analysis of a nanostructured M-monolayer compression isotherms developed by the authors. ${ }^{[30 b, 30 c, 31]}$ The area per molecule in a nanoaggregate $\left(A_{\text {mol }}\right)$ is determined from the slope of the approximating line, the $\beta$ value is determined from the initial ordinate of the straight line, which describes a part of $\pi A-\pi$ isotherm corresponding to the stable state of the layer $(\beta=k \mathrm{~T} / n)$. According to the model used, the diameter of a circular M-aggregate may be calculated from its area: $S_{\text {aggr }}=A_{\text {mol }} \cdot n, \quad D_{\text {aggr }}=\sqrt{4 S_{a g g r} / \pi}$. Stable-state compressibility of the layer is $B=\left(A_{i}-A_{f}\right) /\left(\pi_{f}-\pi_{i}\right) A_{i}$, where $\pi_{i}, \pi_{f}$ are initial and final pressure of the range of existence of a stable monolayer, $A_{i}, A_{f}$ are initial and final x-coordinates of the linear part of the $\pi-A$ isotherm, respectively. The separation between boundaries of aggregates is calculated using the formula $d_{i}=\sqrt{4 A_{i} \cdot n / \pi}-\sqrt{4 A_{\text {mol }} \cdot n / \pi}$. The average distance between the molecules in a $\mathrm{M}_{\text {face }}$-aggregate along the water surface is determined as $r=\sqrt{4 A_{\text {mol }} / \pi}-\sqrt{4 A_{\text {proj }} / \pi}\left(A_{\text {proj }}\right.$ - area of molecular projection). Water content in M-aggregates (per molecule) and between them (at the onset point of the stable state) is $w_{i n-M}=A_{m o l}-A_{\text {proj }}$ and $w_{\text {inter }-M}=A_{i}-A_{\text {mol }}$, respectively. The geometry parameters of molecules were determined from corresponding molecular models built in the HyperChem 7.01 software with the $\mathrm{MM}+$ calculation method as follows: the area of projection $A_{\text {proj(face) }}=1.72 \mathrm{~nm}^{2}, A_{\text {proj(edge) }}=0.72$ $\mathrm{nm}^{2}$; the areas of circumscribed rectangles are $2 \mathrm{~nm}^{2}$ and 1 $\mathrm{nm}^{2}\left(\mathrm{~S}_{\text {face }}\right.$ and $\mathrm{S}_{\text {edge }}$, respectively); and in a densely packed monolayer $A_{\text {mod(face) }}=1.93 \mathrm{~nm}^{2}$ and $A_{\text {mod(edge) }}=0.96 \mathrm{~nm}^{2}$.

From a quantitative analysis of compression isotherms plotted in $\pi-A$ and $\pi A-\pi$ axes one can conclude that stable monolayers of ZnTPP are formed within the studied range of initial degree of water surface coverage. Main results of the analysis and parameters of ZnTPP floating layers are presented in the Table 1 . With the $2.25 \cdot 10^{-5} \mathrm{~mol} \cdot \mathrm{L}^{-1}$ solution at low degrees of surface coverage face-on monolayers are formed ( $c_{\text {face }}$ from 8 to $12 \%$ ).

The monolayers have high aggregation numbers $(n=11)$ and high water content in aquaaggregates and between them: $81 \%$ of $A_{m o l}$ and $1.2 \mathrm{~nm}^{2}$ per a ZnTPP molecule, respectively $\left(c_{\text {face }}=12 \%\right)$. The monolayer parameters depend on the initial degree $c_{\text {face }}$ of surface coverage as follows (Figure 1):

- the area per molecule in a nanoaggregate: $A_{\text {mol }}=110 / c_{\text {face }}$;

- the aggregation number: $n=2,29+0,71 \cdot c_{\text {face }}$.

The dependencies found allow one to estimate the highest aggregation number $n_{\max }=37.8\left(A_{\bmod (\text { face })}=1.93 \mathrm{~nm}^{2}\right)$.

Scheme illustrating the key structural parameters of the ZnTPP monolayers with face-on M-aggregates are presented at Figure 2.

The size (diameter) of the face-on M-aquaaggregates does not depend on the initial degree of surface coverage $\left(D_{\text {aggr }}=11.5 \mathrm{~nm}\right.$, Table 1$)$, what is a specific feature of this compound.

\section{Conclusions}

It is shown that at different initial surface coverage one can create floating monolayers having varying structure 
Table 1. Characteristics of floating layers of ZnTPP, obtained with different initial degrees of surface coverage

\begin{tabular}{|c|c|c|c|c|c|c|c|c|c|c|c|c|}
\hline $\begin{array}{c}c_{\text {face, }} \\
\%\end{array}$ & $\begin{array}{l}\text { Nanoaggregate- } \\
\text { type }\end{array}$ & $\begin{array}{c}c_{i-f a c e}-c_{f-f a c e} \\
\% \\
\left(\Delta c_{j-f a c e}\right) \\
{\left[c_{i-a g g r}\right]}\end{array}$ & $\begin{array}{l}\pi_{i}-\pi_{f}, \\
(\Delta \pi), \\
\mathrm{mN} / \mathrm{m}\end{array}$ & $A_{\text {mol }}$ & $N$ & $\begin{array}{c}D_{a g g r} \\
\left(S_{a g g r}\right), \\
\mathrm{nm}\left(\mathrm{nm}^{2}\right)\end{array}$ & $\psi^{\circ}$ & $\begin{array}{l}w_{i n-M}{ }^{\prime} \\
A_{m o l} \%\end{array}$ & $\begin{array}{l}w_{\text {inter-M-M }}{ }^{2} \\
\mathrm{~nm}^{2}\end{array}$ & $r, \mathrm{~nm}$ & $\begin{array}{c}d_{i} \\
\mathrm{~nm}\end{array}$ & $\begin{array}{c}B, \\
\mathrm{~m} / \mathrm{N}\end{array}$ \\
\hline 8 & $\begin{array}{c}\text { Mono face } \\
\left(M_{\text {face }}\right)\end{array}$ & $\begin{array}{l}12-13 \\
(1)^{[97]}\end{array}$ & $\begin{array}{l}0-2.5 \\
(2.5)\end{array}$ & 14 & 8 & $\begin{array}{c}12 \\
(121)\end{array}$ & 0 & 87 & 1.2 & 4.3 & 0.5 & 32 \\
\hline 9 & $\begin{array}{c}\text { Mono face } \\
\left(M_{\text {face }}\right)\end{array}$ & $\begin{array}{l}13-15 \\
(2)^{[91]}\end{array}$ & $\begin{array}{l}0-2 \\
(2)\end{array}$ & 12 & 9 & $\begin{array}{c}12 \\
(118)\end{array}$ & 0 & 84 & 1.5 & 4 & 0.7 & 56 \\
\hline 10 & $\begin{array}{l}\text { Mono face } \\
\left(M_{\text {face }}\right)\end{array}$ & $\begin{array}{l}15-17 \\
(2)^{[96]}\end{array}$ & $\begin{array}{l}0-2 \\
(2)\end{array}$ & 11 & 9 & $\begin{array}{c}11 \\
(96)\end{array}$ & 0 & 82 & 1.6 & 3.7 & 0.8 & 68 \\
\hline 12 & $\begin{array}{c}\text { Mono face } \\
\left(M_{\text {face }}\right)\end{array}$ & $\begin{array}{l}18-21 \\
(3)^{[94]}\end{array}$ & $\begin{array}{l}0-1.5 \\
(1.5)\end{array}$ & 9 & 11 & $\begin{array}{c}11 \\
(100)\end{array}$ & 0 & 81 & 1.2 & 3.4 & 0.7 & 81 \\
\hline
\end{tabular}

$c_{\text {face }}, \%$ the face-on initial degree of surface coverage; $c_{i \text {-face }}$ and $c_{\text {fface }}$ the degrees of surface coverage at the outermost points of the region of the stable state, respectively, $c_{i-a g g r}$ the degree of coverage of water surface by aggregates at the onset point of a stable state; $A_{m o l}$ the area per molecule in a nanoaggregate; $\pi_{\mathrm{i}}-\pi_{\mathrm{f},}(\Delta \pi)$, the pressure interval of existence of a stable state; $n$ the aggregation number; $D_{\text {aggr }}$ and $S_{\text {aggr }}$ are the nanoaggregate diameter and surface area, respectively; $\psi$ is the tilt angle of molecules; $w_{\text {in- } M}$ and $w_{\text {inter }-M-\mathrm{i}}$ are the bound water content in M-aggregates and the water content per molecule between aggregates at the initial point of the stable state, respectively; $r$ is the average distance between molecules in the aggregates; $d_{\mathrm{i}}$ is the distance between nanoaggregates at the onset point of the stable state; and $B$ is the layer compressibility.

a)

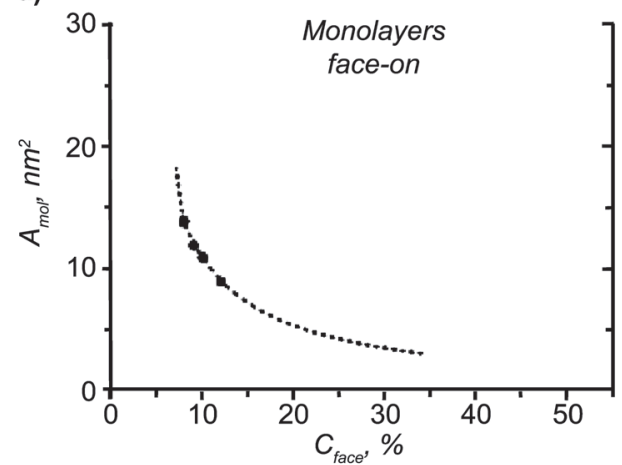

b)

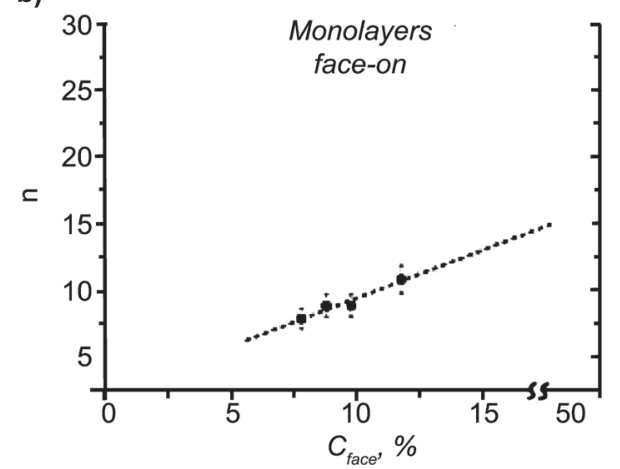

Figure 1. The dependence of area per molecule in the M-aggregate (a) and aggregation number (b) on the initial degree of surface coverage.

with $\mathrm{M}_{\text {face }}$ aqua-aggregates of zinc tetraphenylporphyrinate. With the use of quantitative analysis of isotherms the main parameters of the structure of M-nanoaggregates have been determined: the size of M-nanoaggregates formed within the layer, the number of molecules in the aggregates, the separation between the aggregates, the water content in the aggregates and between them, the value of compressibility, the range of pressure and surface concentration where the monolayers exist. It is shown that in this compound the size (diameter) of face-on M-aquaaggregates is uniquely independent of initial degree of surface coverage $\left(D_{\text {aggr }}=11.5 \mathrm{~nm}\right)$.

Acknowledgements: This work was partially supported by the Russian Foundation for Basic Research (Project N 12-02-00015a) and Ministry of Education and Science of Russian Federation (State task for ISUCT).

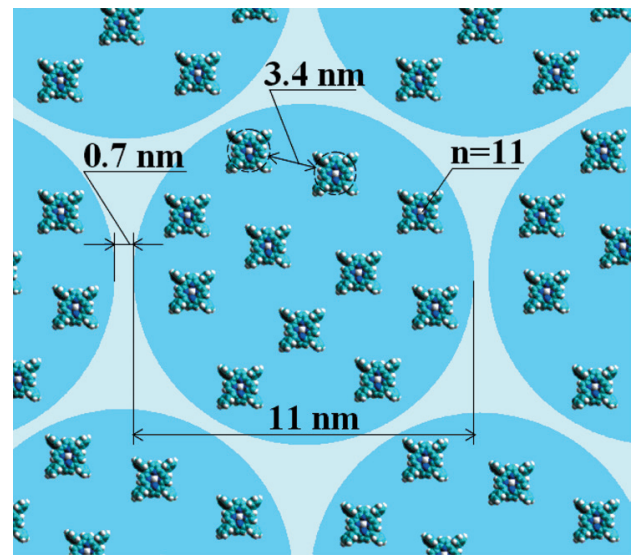

Figure 2. Scheme illustrating the model and the key structural parameters of the ZnTPP monolayer with face-on M-aggregates $\left(c_{\text {face }}=12 \%\right)$. 


\section{References}

1. a) Valli L. Langmuir-Blodgett Films. In: Thin Solid Films: Applications, Preparation and Characterization (Trusso S., Mondio G., Neri F., Eds.), Research Signpost, Trivandrum, India, 2003, Cap. 5, pp. 71-94; b) Valkova L., Borovkov N., Rustichelli F. Organic Nanomaterials for Sensor Devices. Part 1. Application of Supramolecular Materials to Solve Specific Sensor Problems. In: Proceedings of the International School on Advanced Material Science and Technology, 2002, Italy (Dobatkin S., Rustichelli F., Eds.), Tipolitografia Coopergraf, Ancona, 2004, 215-228.

2. Valkova L., Borovkov N., Rustichelli F. Organic Nanomaterials for Sensor Devices. Part 2. Azaporphyrin films as biomimetic sensor materials. In: Proceedings of the International School on Advanced Material Science and Technology, 2002, Italy (Dobatkin S., Rustichelli F., Eds.), Tipolitografia Coopergraf, Ancona, 2004, 229-241.

3. a) Konev D.V., Devillers C.H., Lizgina K.V., Zyubina T.S. Zyubin A.S., Maiorova-Valkova L.A., Vorotyntsev M.A. Electrochimica Acta 2014, 122, 3; b) Valkova L., Borovkov N., Koifman O., Kutepov A., Berzina T., Fontana M., Rella R., Valli L. Biosens. Bioelectron. 2004, 20, 1177; c) Valkova L., Borovkov N., Kopranenkov V., Pisani M., Bossi M., Rustichelli F. Mater. Sci. Eng., C 2002, 22, 167.

4. Topchieva I.N., Osipova S.V., Banatskaya M.I., Val kova L.A. Doklady Akademii Nauk 1989, 308, 910.

5. a) Erokhina S., Erokhin V.Aggregated Layers of Semiconductor Nanoparticles Formed in Langmuir-Blodgett Films. In: Supramolecular Engineering of Conducting Materials (Ram M.K., Ed.), Research Signpost, 2005, 224-235; b) Val'kova L.A., Val'kov S.V. Kolloidnyi Zh. 1985, 47(3), 632-634 (in Russ.); c) Val'kova L.A., Val'kov S.V. Kolloidnyi Zh. 1986, 58(4), 835 (in Russ.).

6. Mineev L.I., Val'kova L.A., Shabyshev L.S., Chistyakov I.G. J. Exp. Theor. Phys. 1981, 53, 1020.

7. Aleksandrov A., Valkova L., Radnyuk V., Strelzov S. Device for X-ray Diffraction Study of Oriented Liquid Crystal Compounds Patent N1356717 (1.08.1987) (Russ.).

8. Valkova L.A. Formation and Small-Angle X-Ray Investigation of LB-Films of Discogens-Tetraalkoxyhydroquinones, Copper Carboxylates and Hexaheptyloxytriphenylenes, Synopsis of the PhD (in Phys. and Math.) Thesis, Moscow, 1993, 19 p. (in Russ.).

9. Elemans J.A.A.W., Hameren R.V., Nolte R.J.M., Rowan A.E. Adv. Mater. 2006, 18, 1251.

10. Gryko D.T., Fox J.P., Goldberg D.P. J. Porphyrins Phthalocyanines 2004, 8, 1091.

11. Srinivasan A., Furuta H. Acc. Chem. Res. 2005, 38, 10.

12. Bogdanovskaya V.A., Beketaeva L.A., Rybalka K.V., Efremov B.N., Zagudaeva N.M., Sakashita M., Lidzima T., Ismagilov Z.R. Russ. J. Electrochem. 2008, 44, 293.

13. a) Basova T., Kol'tsov E., Hassan A.K., Ray A.K., Gürek A.G., Ahsen V. Mater. Chem. Phys. 2006, 96, 129; b) Valkova L.A., Shabyshev L.S., Feigin L.A., Akopova O.B. Molecular Materials 1996, 6, 291; c) Valkova L., Rustichelli F., Pisani M., Maccioni F., Bernstorff S. IBN ELETTRA Annual Report 2000, Austrian SAXS Beamline at ELETTRA Synchrotron Trieste, Italy, 2000, 64-65.

14. a) Alexandrov A.I., Krasnov A.V., Pashkova T.V. Synthetic Metals. 2004, 147/1-3, 205; b) Valkova L.A., Shabyshev L.S., Feigin L.A., Akopova O.B. Bulletin of the Russian Academy of Sciences: Physics 1997, 61, 3, 631; c) Valkova L.A., Lvov Y.M., Feigin L.A. Biologicheskie Membrany 1991, 6, 656 (in Russ.).

15. a) Ariga K., Hill J.P., Wakayama Y. Phys. Stat. Sol. 2008, 205, 1249; b) L. Valkova, V. Erokhin \& L.A. Feigin Molecular Crystals and Liquid Crystals 1992, 215, 363.
16. a) Aleksandrov A.I., Pashkova T.V., Dronov V.M. Molecular Materials 2001, 14, 3; b) Valkova L., Borovkov N., Koifman O., Rustichelli F. Crown Ether Nanomaterials for Sensing of Organic Molecules. In: Proceedings of the International School on Advanced Material Science and Technology, 2002, Italy (Dobatkin S., Rustichelli F., Eds.), Tipolitografia Coopergraf, Ancona, 2004, 69-93; c) Valkova L.A., Shabyshev L.S., Borovkov N.Yu., Valkov A.S. Proc. of Intern. Symp. Thin Films in Electronics, Ples, Russia, 1998 pp. 28-34.

17. a) Valkova L., Borovkov N., Pisani M., Rustichelli F. Thin Solid Films 2001, 401, 267; b) Valkova L., Borovkov N., Maccioni E., Pisani M., Rustichelli F., Erokhin V., Patternolli C., Nicolini C. Colloids Surf., A 2002, 198-200, 891.

18. a) Fokin D., Valkova L.A., Sibrina G.V., Koifman O.I. Proceedings of XII Youth Conference on Organic Chemistry 7-11 December 2009, Suzdal, 410-413 (in Russ.); b) Valkova L.A., Klechkovskaya V.V., Sorokin K.L., Yanusova L.G. Izv. Vyssh. Uchebn. Zaved., Mater. Elektron. Tekhn. 1999, 4, 70 (in Russ.).

19. a) Valkova L.A., Valli L., Casilli S., Borovkov N.Y., Sibrina G.V., Glibin A.S., Koifman O.I., Pisani M., Rustichelli F. Langmuir 2008, 24, 4857; b) Valkova L., Menelle A., Borovkov N., Erokhin V., Pisani M., Ciuchi F., Carsughi F., Spinozzi F., Pergol M., Padke R., Bernstorff S., Rustichelli F. J. Appl. Crystallogr. 2003, 36, 758.

20. a) Erokhin V., Carrara S., Paternolli C., Valkova L., Bernstorff S., Nicolini C. Appl. Surf. Sci. 2005, 245, 369; b) Val'kova L.A., Klechkovskaya V.V., Yanusova L.G., Ivakin G.I., Sorokina K.L., Feigin L.A. Poverkhnost': Rentgenovskie, Sinkhrotronnye i Neitronnye Issledovaniya 2000, 9, 82 (in Russ.) [Val'kova L.A., Klechkovskaya V.V., Yanusova L.G., Ivakin G.I., Sorokina K.L., Feigin L.A. J. Surf. Investigation: X-Ray, Synchrotron and Neutron Techniques 2001, 16, 1485].

21. a) Valkova L., Borovkov N., Pisani M., Rustichelli F. Langmuir 2001, 17, 3639; b) Val kova L.A., Shabyshev L.S., Klechkovskaya V.V. Liquid Crystals and Application 2002, 2, 61 (in Russ.); c) Valkova L.A., Chernyshova T.A., Shabyshev L.S. Liquid Crystals and Application 2004, 3-4, 42 (in Russ.).

22. a) Glibin A.S., Valkova L.A., Sibrina G.V., Koifman O.I. Proceedings of XII Youth Conference on Organic Chemistry 7-11 December 2009, Suzdal, 237-239 (in Russ.); b) Valkova L.A., Shabyshev L.S., Borovkov N.Yu., Feigin L.A., Rustichelli F. J. Inclusion Phenom. Macrocyclic Chem. 1999, 35, 243.

23. Valkova L., Glibin A., Gromova O., Borovkov N., Koifman O., Shilyaev R., Rustichelli F. Fullerenes: Prospects of Medical Application and Aggregation Behavior" In: Proceedings of the International School on Advanced Material Science and Technology, 2005, Italy (Dobatkin S., Rustichelli F., Eds.), Tipolitografia Coopergraf, Ancona, 2006, 16-35.

24. a) Basova T., Paul S., Paul D., Vadgama P., Gurek A. G., Ahsen V., Ray A. J. Bionanoscience 2008, 2, 114; b) Gromova O.A., Sotnikova N.Y., Valkova L.V. et al. Russ. J. Immunology 2004, 1,16 .

25. Gromova O.A., Tretyakov B.E., Moshkovsky S.A., Gusev E.I., Nikonov A.A., Valkova L.A., Glibin A.S., Kataev A.S. Zh. Nevrol. Psikhiatr. im. S.S. Korsakova 2006, 106(7), 68 (in Russ.).

26. a) Valkova L., Borovkov N., Koifman O., Rustichelli F. Organic Nanomaterials for Sensor Application. Fullerene Composites. In: Proceedings of the International School on Advanced Material Science and Technology, 2003, Italy (Dobatkin S., Rustichelli F., Eds.), Tipolitografia Coopergraf, Ancona, 2004, 94-118.

27. Volmer M. Z. Phys. Chem.(Leipzig) 1925, 115, 253.

28. Myagkov I., Studnev Y. Kolloidnyi Zh. 1985, 157, 715 (in Russ.).

29. a) Valkova L.A., Betrencourt C., Hochapfel A., Myagkov I.V., Feigin L.A. Mol. Cryst. Liq. Cryst. 1996, 287, 269; b) Valkova L.A., Klechkovskaya V.V., Yanusova L.G., Ivakin G.I., Sorokina 
K.L., Feigin L.A. Proceedings of II National Conference on Application of X-Ray Synchrotron Beams, Neutrons and Electrons for Study of Materials, Moscow, 1999, 82-86.

30. a) Filimonov A.V., Valkova L.A., Ososkov G.A. Neural network approach to study of Langmuir layers at the water surface http://arxiv.org/abs/physics/0401038 physics 2004, 0401038 b) Valkova L.A., Glibin A.S., Valli L. Kolloidnyi Zh. 2008, 70(1), 11 (in Russ.) [Colloid J. 2008, 70, 6]; c) Valkova L.A., Zyablov S.V., Erokhin V.V., Koifman O.I. J. Porphyrins Phthalocyanines 2010, 14, 513.

31. Maiorova L.A. Controlled Self-Assembling of Azaporphyrins in 2D- and 3D-Nanostructures in Langmuir Layers and Langmuir-Blodgett Films, Synopsis of Doctor of Sciences (Phys. and Math.), Thesis, Ivanovo, 2012, 32 p.
32. a) Valkova L.A., Erokhin V.V., Glibin A.S., Koifman O.I. $J$. Porphyrins Phthalocyanines 2011, 15, 1044; b) Valkova L.A., Glibin A.S., Koifman O.I. Macroheterocycles 2011, 4, 222.

33. Karlyuk M.V., Krygin Yu.Yu., Maiorova-Valkova L.A., Ageeva T.A., Koifman O.I. Izv. Acad. Nauk, Ser. Khim. 2013, N. 2, 0471-0479 (in Russ.) [Russ. Chem. Bull. 2013, 62, 471].

34. a) Krygin Yu.Yu., Petrova M.V. , Maiorova-Valkova L.A., Ageeva T.A. , Koifman O.I. Dizain. Materialy. Tekhnologiya 2013, 5(30), 68 ( in Russ.); b) Valkova L., Valli L. , Casilli S., L. Valkova, N. Borovkov, O.I. Koifman J. Porphyrins Phthalocyanines 2004, 8, 4-6, 881.

35. Semeykin A., Koifman O., Berezin B. Khim. Geterotsykl. Soed. 1986, 6, 798 (in Russ.) 